Asian Development Policy Review

$\operatorname{ISSN}(e):$ 2313-8343

$\operatorname{ISSN}(p): 2518-2544$

DOI: $10.18488 /$ journal.107.2021.91.44.56

Vol. 9, No. 1, 44-56.

(C) 2021 AESS Publications. All Rights Reserved.

URL: wwrw.aessweb.com

\title{
EXPLORING THE IMPACT OF EXPORTS ON CLEAN ENERGY
CONSUMPTION IN CHINA: AN EMPIRICAL STUDY
}

Abdelrahim A. M. Yahia $^{1+}$

(iD) Zhaohua $\mathbf{L i}^{2}$
(iD) Ebaidalla Mahjoub
Ebaidalla
(iD) Jun $\mathbf{H e}^{4}$

Jun $\mathrm{He}^{4}$

\author{
${ }^{\prime}$ School of Economics, Huazhong University of Science and Technology, \\ Wuhan, China and Department of Economics, University of Kassala, \\ Kassala, Sudan. \\ Email:abdelrahim2uofk@gmail.com Tel:+249911202826 \\ ${ }^{2}$ School of Economics, Huazhong University of Science and Technology, \\ Wuhan, China. \\ Email:shaohuali@hust.edu.cnTel:+8613100705171 \\ ${ }^{s}$ Department of Economics, University of Khartoum, Khartoum, Sudan. \\ Email:ebaidalla@gmail.com Tel:+249912636114 \\ ${ }^{4}$ School of Economics, Huazhong University of Science and Technology, \\ Wuhan, China. \\ Email:371638810@qq.com Tel:+8615671660175

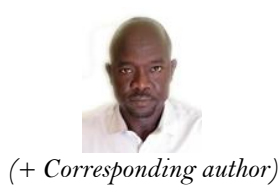

ABSTRACT

Article History

Received: 19 August 2020 Revised: 10 February 2021 Accepted: 17 March 2021 Published: 15 April 2021

\section{Keywords}

Clean energy consumption Exports

Technological innovation ARDL bounds testing

Vector error correction model (VECM)

China.

\section{JEL Classification}

F14: Empirical Studies of Trade F18: Trade and Environment F64: Economic Impacts of Globalization: Environment Q01: Sustainable Development
Understanding the influence of export volume in improving a country's clean energy consumption requires a systematic search method to characterize the crucial role to ensure environmental sustainability. The present study employed an autoregressive distributed lag (ARDL) bounds testing approach and vector error correction model (VECM), by using data from 1985-2018. The analysis revealed that in the long-run an increase in exports per capita and technological innovation can enhance clean energy consumption, and overcome environmental issues. Surprisingly, economic growth does not display significant effect. In the short run technological progress reduces clean energy consumption. The outcome of causality tests reveals a unidirectional from technological innovation to clean energy consumption in the short term. Along similar line, the results prove a feedback link among exports per capita and clean energy consumption, indicating that an increase in exports per capita is a core factor driving and improve energy use, among technological innovation and clean energy consumption, and among economic growth and clean energy consumption in the long run. To enhance clean energy and enable success in environmental improvement, policymakers in China should take proper initiatives to increase the clean trade, adjust the export pattern, and patent incentive technology, to ensure sustainable economic development.

Contribution/ Originality: This study is one of very few studies which have investigated the role of exports in clean energy consumption in China, and contributes to the existing literature by employing the ARDL bounds testing approach and VECM to investigate the short-run and long-run interconnections.

\section{INTRODUCTION}

Energy pervades in most sectors of the economy, therefore, to achieve adequate and reliable energy consumption depends on economic growth. As the countries move along its growth path, China enjoys energy-led growth, it is demand for energy consumption rises with economic growth. So, China remained in the largest energy 
consumer in the world until 2009, with almost 22 percent of total global energy consumption in 2018 (GESY, 2019). According to the National Bureau of Statistics of China, the most portion of this energy comes from the consumption of coal, they represent about 59 percent of China's energy consumption in 2018. Therefore, the use of this type of energy has the related effect of harming the environment which causes global climate change through an increase in carbon dioxide ( $\mathrm{CO} 2)$ emission, sulfur dioxide, etc. As a nation becomes more interested to follow the path of international trade, growth and green investment, this situation provided policymakers in China, the opportunity to pay more attention to increase exports as important factors to driver clean energy consumption.

Clean energy, indicates the energy that does not emit pollutants, such as solar energy, hydropower, wind power, tidal energy, and nuclear energy. While China is the largest in coal consumption, it also is greener than anyone else. It was responsible for 32 percent of all global sources of renewable energy in 2018, such as hydropower, solar photovoltaic (PV) and wind. The debate on the role of export plays in determining clean energy consumption has at times generate more heat than light. The series identifies the hypotheses linking exports and clean energy consumption has been successful in theoretical work, but it is seriously lagged in empirical verification. In recent, the most studies focusing on the relationship between exports/trade and energy consumption (Chen, Wang, \& Zhong, 2019; Dedeoğlu \& Kaya, 2013; Nasreen \& Anwar, 2014; Sadorsky, 2011; Tiba \& Frikha, 2018). However, the recent literature review has not given sufficient attention to the linkage between exports/trade and clean energy consumption. A study conducted by Sebri and Ben-Salha (2014); Shahbaz, Khan, and Tahir (2013); Sohag, Begum, Abdullah, and Jaafar (2015) revealed that an increase in export volume contributes to economic activity and this might increase energy consumption, therefore, exports, income, and energy tend to move together over time. Moreover, some scholars focused widely on renewable energy consumption e.g., (Ben Jebli, Ben Youssef, \& Apergis, 2014; Chen et al., 2019). In addition, some researches tend to use the ARDL bounds test to analyse the link between that international trade and renewable energy consumption such as Alam and Murad (2020); Brini, Amara, and Jemmali (2017) but authors do not discuss their results in terms of specification tests of the ARDL bounds to investigate the role of exports volume in clean energy sources such as hydropower, nuclear power, and wind. Therefore, our study aims to fill the gaps. China is well endowed with renewable sources of energy; therefore it is important to investigate the relationship between clean energy consumption and international trade. Thus, the paper provides significant contributions as follows:

First, employ the autoregressive distributed lag (ARDL) bounds testing approach and vector error correction model (VECM), to investigate the role of exports in clean energy consumption in China in terms of the short and long-run links, as well as explain Granger causality between the variables. To the best of our knowledge, the kind of this research has not given sufficient attention in China, and this will offer new empirical evidence for the policymaker to improve clean energy use. Second, clean energy sources such as hydropower, nuclear power, and wind power have been neglected in international trade literature abroad, so far probably due to the lack of longtime series data in most countries, such as China.

Therefore, this study also aims to fulfill this lack and contributes to the existing literature. Moreover, the linkage between export and clean energy use makes more theoretical sense due to the boom and the ability, to keep a green economy and has significant implications for China government and policymakers. To achieve these aims, the study used the ARDL bounds testing approach and VECM model to infer exports and clean energy consumption causal relationships. The rest of the paper is organized as follows. In section 2 we provide a brief history of clean energy consumption in China, while section 3 provides the methodology. In section 4 the study presents empirical results and section 5 conclusion and policy implementation.

\section{OVERVIEW OF CHINA'S CLEAN ENERGY CONSUMPTION}

China is an interesting state to study the role of exports in clean energy consumption because it has experienced rapid economic growth since the open door reform policy in 1978, the clear signs of growth were 
driven by the volume of exports, and in 2010 it became the second-largest economy in the world. China's economy depends in large part on tertiary and secondary industries which together make up $95.80 \%$ of China's GDP growth in 2018, exports played a significant part in China's economic growth, the share of exports of goods and services accounted on average about (19.51\% of GDP) in 2018, most China's exports rely heavily on of manufactured goods which represent by $80.12 \%$ of total exports. In 2018 total energy consumption in China reaches 4.49 billion tce, which increased by the annual growth rate is $33.58 \%$ more than at the beginning time which has become the largest country consume energy in the world in 2009. Due to its rising energy consumption, China has had to become more demanded clean energy sources to meet its emissions'. Therefore, China has a relatively extensive set of policies applied to improve the environment and energy use, the real attention of its policies have their roots in 2011 during the $12^{\text {th }}$ Five-Year-Plan (FYP) Period, to control greenhouse gas emissions from 2011-2015 (Yuan, Xu, Zhang, Hu, \& Xu, 2014). In June 2014 China's president made calls for an "energy revolution", this program guidance for Energy Production and Consumption Revolution Strategy (2016-2030), target to cover energy demand incremental mainly by clean energy (WEO, 2017). After this implementation, the miracle of China's clean energy consumption was enabled at a two-digit growth rate Figure 1.

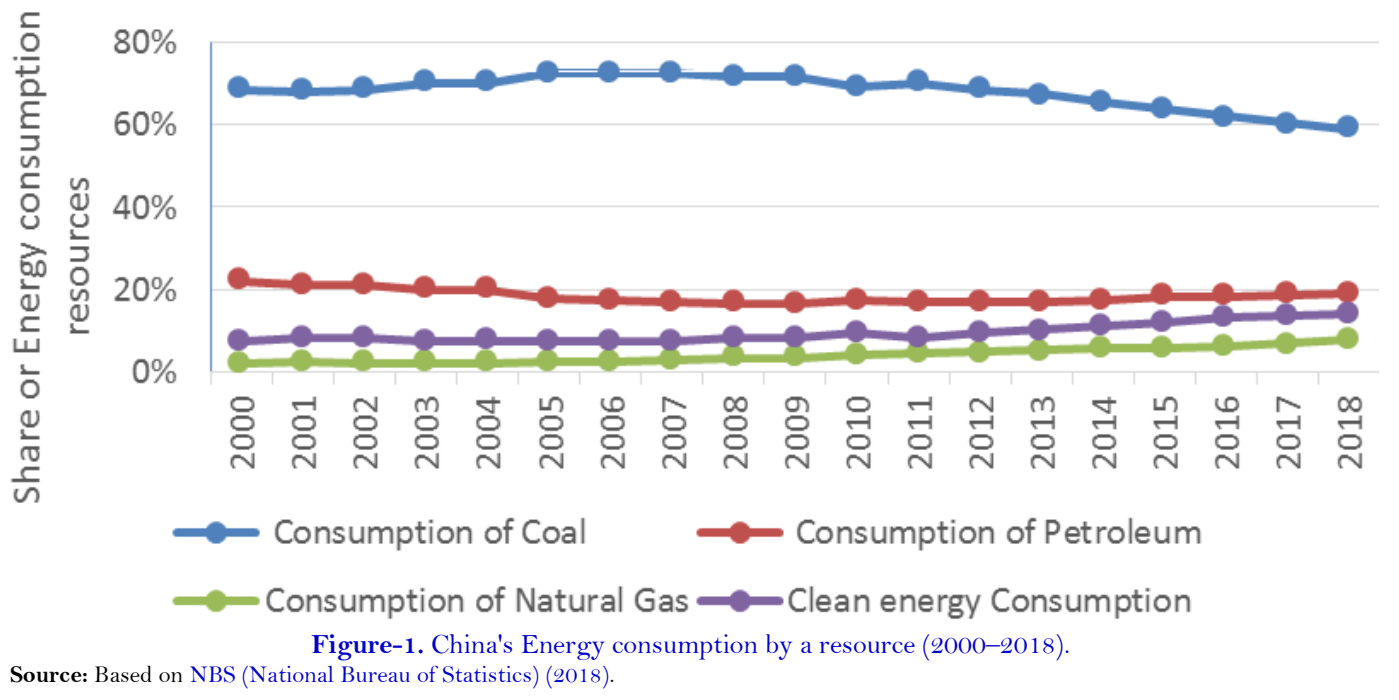

Clean energy consumption (Hydro Power, Nuclear Power, and Wind Power) in China has increased steadily simultaneously with the rapid increase in energy consumption. It is increased fivefold from 10,728.37, million tce in 2000 to 66,352 Mtce in 2018, this is one of the important observations which excites the interests of our study. Since 2000, however, other energy sources such as natural gas do not feature as a significant energy source Figure 1. Shows that between 2000 and 2017 clean energy increased steady, its share of energy consumption increased from 7.3 to 13.8 percent. The increase in coal share due to the abundance of coal in China and exist advanced industrialization, hence, industries were used more energy resources such as coal, oil, use of private automobiles, etc. As illustrated in Figure 2 Recently, China became one of the largest exports in the global and its path of emissions from $\mathrm{CO} 2$, for example, has closely followed the path of energy consumption. Thus, the sharp increase in export volume caused by the economic structure and the manufacturing industry. The state data also exhibits some remarkable patterns, the average of China's annual growth rate of export is $15.30 \%$ during the period "between" 2000 to 2018, this will reflect in China's energy structure. It can be clearly shown that exports grow strongly and consistently with an upward trend, also clean energy consumption increases consistently with exports trend Figure 2. Although the government regulations continue in playing a curial role in energy use, and economic growth this will reflect on international trade. 

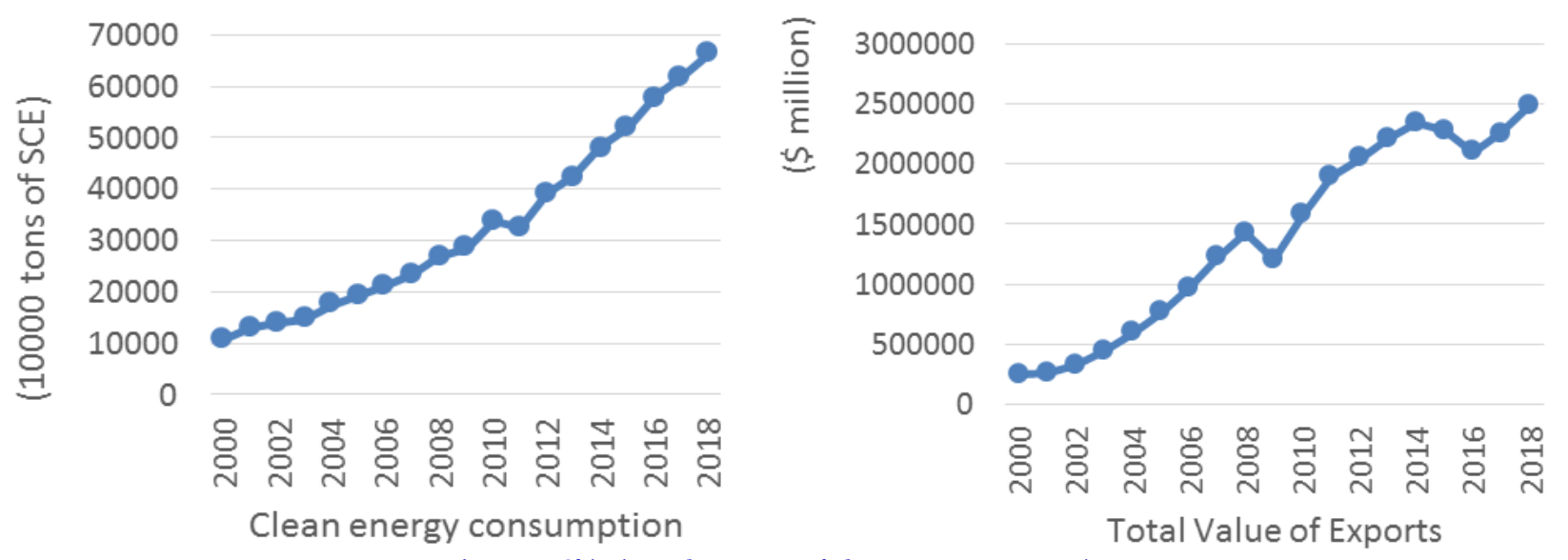

Source: NBS (National Bureau of Statistics) (2018).

Figure-2. China's total exports and clean energy consumption.

\section{METHODOLOGY}

\subsection{Model Specification}

The study focuses on China because it is leading the way in clean energy use, as well as the high technical level for the efficient use of energy recently. For example, the consumption of clean energy in China increased more than five times in 18 years from 10,728.37 million tce in 2000 to 66,352 Mtce in 2018 (NBS, 2019). To test whether the export volume has a systematic relationship with the clean energy in China, the study depends on time series data, and adopt the ARDL technique using an error correction model (ECM). Following the methodology of Pesaran, Shin, and Smith (2001) and Narayan (2005) the present work considers the effect of exports on clean energy in the presence control variables in a multivariate framework. Thus, the functional form of the model as follows:

$$
C E C=f(E X, T I, G D P G)
$$

Where CEC is the clean energy consumption, EX denotes export volume, TI is technological innovation, and GDPG represents the economic growth.

The specific form of Equation 1 might be transformed into log-linear functional as follows:

$$
L n C E C_{t}=\beta_{0}+\beta_{1} \operatorname{LnEX}_{t}+\beta_{2} \operatorname{LnTI}_{t}+\beta_{3} \operatorname{LnGDPG_{t}}+\varepsilon_{t}
$$

Where Ln, CEC, EX, TI, and GDPD indicate the natural-log of those variables as defended earlier, while " $\varepsilon$ " is a residual error term, it assumed to be a normal distribution with zero mean and constant variance, and " $t$ " refers to time. The parameters $\beta \mathrm{i}(\mathrm{i}=0,1,2,3)$ are the long-run elasticities corresponding to each explanatory variable. Thus, Equation 2 is a basic equation for the level of PM2.5 in provinces at time t. Therefore, our study included important variables and their sources according to the following evidence and items:

First, technological innovation; mostly improves the clean energy use by technological progress, while it reduces energy consumption slightly, i.e., through allow the economy to produce a certain level of output depending on a lower level of energy by augmenting energy efficiency. Furthermore, it provides opportunities for the economy to transfer into the demand of renewable energy sources (Brock \& Taylor, 2005; Chen, Cheng, \& Dai, 2017; Pan, Ai, Li, Pan, \& Yan, 2017; Yuan \& Zhang, 2020) emphasized that technological innovation is beneficial for protecting the environment and contributes to the protection of natural resources.

China has considerable experience in technological innovation that leads to achieving a developed country in the near future. Therefore, the patent index is a fundamental index to measure technological innovation as a proxy because the patent it indicated the outcome of research and development which found concern from most organizations and industry to explore new technology (Acs, Anselin, \& Varga, 2002; Pan, Uddin, Han, \& Pan, 2019; Sohag et al., 2015). Accordingly, patent applications in China will use to measure technological innovation in this study. It is natural to expect that a larger economic growth country to have better technologies. Therefore, we 
argue that technological innovation levels in China should be allowed to depend positively on clean energy consumption. Second, economic growth; understand the role of economic growth on clean energy consumption it is more important for policymakers to design rational clean energy policies according to the economic level of a certain country. Many scholars argued that the country's economic growth has resulted in an expansion in economic activities, which is strongly related to energy use, for example (Amri, 2017; Lean \& Smyth, 2010; Ocal \& Aslan, 2013) pointed out that economic growth has a positive impact significant on clean energy consumption. Some scholars argued exists a unidirectional causality running from economic growth to clean energy use (Rahman \& Velayutham, 2020; Shahbaz \& Feridun, 2012) others declare a bidirectional causality exists between both variables (Lin \& Moubarak, 2014; Sebri \& Ben-Salha, 2014) and some outcomes contradict, i.e. there is no exists causality between the two variables under consideration (Menegaki, 2011). Thus, unlike previous literature that has mostly analysed the impact of energy use on economic growth, this study examines whether economic growth can affect clean energy use as well as stimulate policies that aim to reserve energy use. Accordingly, the study uses GDP growth as a proxy for economic growth. Earlier studies have been proved that economic growth positively correlated with clean energy, therefore, we also expect the same.

In the recent literature regard with co-integration analysis between the variables $\mathrm{I}(1)$, is no longer applicable to the traditional ARDL approach (Pesaran \& Shin, 1998). Consequently, Engle and Granger (1987); Johansen (1991); Phillips and Hansen (1990) and others, are the pioneer scholars who have been developed co-integration for analysis of I(1) variables. Pesaran and Shin (1998) re-examine the form into traditional identity labelled ARDL model, to test whether there is a relationship between variables considering first-order integrated I(1) and level order variables or not. In order to address this limitation, Pesaran et al. (2001) developed the form into the ARDL bounds test technique, which is applicable nevertheless of whether the regression models are purely $\mathrm{I}(0)$, purely $\mathrm{I}(1)$ or jointly co-integrated, and it permits to find short-run and long-run elasticity through estimate the ECM. Moreover, this identity will avoid the problem of endogeneity in the model. In addition, this model is appropriate for a small sample size (Narayan, 2005). Thus, The ARDL bounding testing approach for the standard log function among the variable of interest is specified as follows:

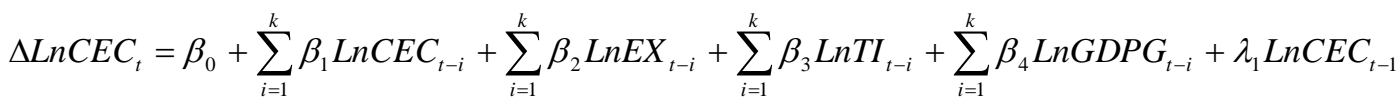

$$
\begin{aligned}
& +\lambda_{2} \operatorname{LnEX}_{t-1}+\lambda_{3} \operatorname{LnTI}_{t-1}+\lambda_{4} \operatorname{LnGDPG_{t-1}}+\varepsilon_{t}
\end{aligned}
$$

Where $\Delta$ represents the first difference operator, while $\mathrm{k}$ is optimal lag lengths. In order to estimate cointegration among the factors, might be applied the ARDL bounds test based on the Joint F-statistics or Wald test, of the coefficients for the lagged levels in Equation 3, under the null hypothesis which assume that no cointegration among the series $\left(\mathrm{H}_{0}: \lambda_{1}=\lambda_{2}=\lambda_{3}=\lambda_{4}=0\right)$ against the alternative hypothesis of exist co-integration $\left(\mathrm{H}_{1}: \lambda_{1} \neq \lambda_{2} \neq \lambda_{3} \neq \lambda_{4} \neq 0\right)$.

In fact that, Pesaran (1997) and Narayan and Smyth (2009) were computed two bounds of critical values (CV) of F-statistics for large sample scope (500-1000 observations) and small sample size (as low as 30) respectively. Accordingly, if the value of F-statistics exceeds the upper critical bounds value, which means the study will confirm the co-integration among the series and vice versa, while if the estimated value of F-statistics falls between the two bounds (lower and upper) of critical values the test is inconclusive.

\subsection{Long-Run and Short-Run Dynamics}

After the confirming co-integration among the series, we continue to estimate (ECM) model, in this regard, Haider, Adil, and Ganaie (2019) argued that ignore the short-run model from the long-run estimation may lead to an instability problem, therefore, to avoid this problem we include short-run estimate in the ARDL model labelled the error-correction model based on Equation 3 by way of substituting the part of long-run relationships (in the last part) with a one-year lagged error correction term $\left(\mathrm{ECM}_{\mathrm{t}-1}\right)$. Thus, Equation 3 provide short-term dynamic 
coefficients as follows:

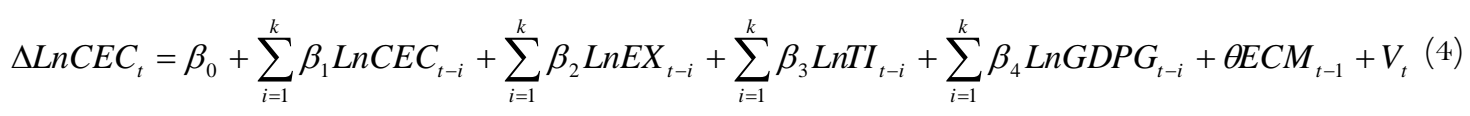

Where $\mathrm{ECM}_{\mathrm{t}-1}$ denotes the error correction term, while " $\theta$ " indicates the speed of adjustment to equilibrium. The ECM included in Equation 4 to capture the short-run deviations of clean energy consumption, exports per capita, technological innovation and economic growth from their long-run equilibrium path, to be interpreted well with the criteria of long-run equilibrium, the estimation coefficient of the ECM must be negative and statistically significant. Nevertheless, this model also allows us to calculate the short-run causality effects, by employing the Wald test statistic of the lag difference coefficient of all explanatory variables.

To check the stability of the ARDL model and to ensure outcomes for policymaking, this study applies robustness tests such as the cumulative sum of recursive residuals (CUSUM), the cumulative sum of the squares (CUSUMSQ), and Ramsey RESET test, etc.

\subsection{Data Acquisition}

Our key source of data in the annual time series comes from the China Statistics (2019) Specifically, the data of clean energy consumption, total exports, and technological innovation, while the data of economic growth comes from world development indicators, which gives us, for the period between 1985 and 2018 , the unique feature of this data is the range of technological innovation during this time period.

\section{RESULTS AND DISCUSSION}

\subsection{Unit Root Analysis}

To obtain a consistent outcome across the variables, our empirical results begins with examining the stationarity properties of the variables, because the testing unit root is the preliminary condition for the ARDL bounds testing technique to co-integration analysis. To prevent spurious regression and unbiased estimates issues, we applied two unit root tests: tests of Augmented Dickey and Fuller (ADF) and Phillips Perron (PP) (Dickey \& Fuller, 1979; Phillips \& Perron, 1988). The results reported in Table 1 propose that in all variables except economic growth in ADF test and exports per capita and economic growth in PP test were found to be a unit root problem at level having intercept and trend, however, after the first difference, we found that all the variables are integrated at (I), i.e., no variable is stationary at level 2 nd difference. The optimal lag order was selected automatically based on the Schwarz information criteria and the Bartlett Kernel using newly and West Band width in the ADF test and PP test respectively. Thus, an implication is that the variables under consideration are eligible to establish ARDL bounds testing approach to test whether the co-integration relationship exists among the series or not.

Table-1. Unit root tests analysis

\begin{tabular}{c|c|c|c|c}
\hline \multirow{2}{*}{ Variable } & \multicolumn{2}{|c|}{ Augmented Dickey-Fuller tests } & \multicolumn{2}{c}{ Phillips Pearson tests } \\
\cline { 2 - 5 } & Level & First difference & Level & First difference \\
\hline LnCEC & 0.881 & $-4.439^{*}$ & 1.091 & $-6.156^{*}$ \\
\hline LnEX & -2.589 & $-3.526^{* *}$ & $-3.008^{* *}$ & $-4.696^{*}$ \\
\hline LnTI & 0.819 & $-3.293^{* *}$ & 1.551 & $-4.840^{*}$ \\
\hline LnGDPG & $-3.769^{*}$ & $-6.401^{*}$ & $-3.189^{* *}$ & $-4.976^{*}$ \\
\hline
\end{tabular}

\subsection{ARDL Bound Testing Results}

To examine the ARDL bounds testing approach for the model and to test whether exist the co-integration relationship among the variables or not, we further investigate the model specification to determine the optimal lag length. The study based on Akaike Information Criteria (AIC) lags to select the suitable lag length, the optimal lags' portrayal for our regression model in a way $(1,0,1,0)$. 
Table-2. Results of ARDL bound test

\begin{tabular}{|c|c|c|c|}
\hline \multirow[t]{2}{*}{ Estimated Model } & \multicolumn{2}{|c|}{ Bound testing to co-integration } & \multirow[b]{2}{*}{ Remarks } \\
\hline & Optimal lag length & F-Statistics & \\
\hline $\mathrm{CEC}=f(\mathrm{EX}, \mathrm{TI}, \mathrm{GDPG})$ & $1,0,1,0$ & $6.059^{*}$ & Conclusive \\
\hline $\begin{array}{l}\text { The critical value for bounds test: } \\
\text { unrestricted intercept and trend }\end{array}$ & Lower bounds I(O) & Upper bounds I(1) & \\
\hline $1 \%$ level & 4.29 & 5.61 & \\
\hline $5 \%$ level & 3.23 & 4.35 & \\
\hline $10 \%$ level & 2.72 & 3.77 & \\
\hline
\end{tabular}

Note: * indicates a significant level at $1 \%$.

Table 2 revealed that there is strong evidence of co-integration, the value of bound F-statistic (6.059) for the model lies above the upper bounds' critical values of the $1 \%$ significance level, hence we reject the null hypothesis of no co-integration among the series. Thus, the results confirm the existence of long-run relationship among variables. In order to check the robustness of the Bounds test of co-integration, by constructing a multivariate cointegration approach (Shahbaz, Loganathan, Zeshan, \& Zaman, 2015; Wang \& Wang, 2018).

Table 3 suggests that there are three co-integrating vectors by trace statistics and the maximum eigenvalue test. Thus, the presence of a co-integrating vector also confirms the existence of a long-run co-integration between the variables, suggesting that the bound test co-integration analysis is robust, effective and reliable.

Table-3. Results of Johansen tests for co-integration

\begin{tabular}{c|c|c}
\hline Hypothesis & Trace statistic & Maximum Eigenvalue statistic \\
\hline $\mathrm{r}=0$ & $86.0985^{*}$ & $43.8473^{*}$ \\
\hline $\mathrm{r}=1$ & $42.2511^{*}$ & $23.9676^{* *}$ \\
\hline $\mathrm{r}=2$ & $18.2835^{* *}$ & $17.5934^{*} *$ \\
\hline $\mathrm{r}=3$ & 0.6901 & 0.6901 \\
\hline Note: ${ }^{*}$ and $* *$ indicates significant at $1 \%$ and $5 \%$ respectively.
\end{tabular}

\subsection{Long-Run and Short-Run Elasticity}

The main task is to assess whether exports have positive effects on clean energy consumption in this setting. Panel A of Table 4 presents the results of the long-run analysis, the results suggest that keeping other things constant, a 1 percent increase in exports per capita is accompanied by a 0.13 percent-improvement in clean energy consumption, an effect statistically significant at the 1 percent level. This finding indicates that promoting export volume can enhance clean energy consumption, and China benefited from international trade through technology used to promote clean energy use. This evidence is similar to Chen et al. (2019); Lee (2013); Sohag et al. (2015) who all report that the increase in exports spurs clean energy consumption.

The common belief about China's exports is that it leads to an increase in the level of income and technical used therefore an increase in clean energy consumption. In fact, after China joined in the world trade organization (WTO) in 2001, the size of exports and the rapid growth in industrialization has been identified as one of the significant factors that can explain the environmental status. Therefore, exports lead to energy use efficiency. Therefore, an increase in economic growth due to an increase in export volume may contribute to efficient technological use, thus, affect not only on economic growth itself but the clean energy consumption as well.

However, this finding differs from the result provided by Brini et al. (2017) for Tunisia, who argued that in the long- term, international trade variables did not lead to an increase in clean energy consumption. Similarly, Kahrl and Roland-Holst (2008) reveal that net export in China increases domestic energy consumption more than in the EU and U.S. As can be seen from Table 4, under an increasing proportion of technological innovation, China's clean energy consumption improved significantly by $0.33 \%$, and it is coefficient is larger than the effect of export per capita. This result indicates that technological progress promotes the efficiency of clean energy consumption. This finding identifies that China focuses more on technological innovation to overcome environmental issues and ensure 
clean energy use. This empirical result is consistent with the evidence of Aznar-Sánchez, Velasco-Muñoz, Belmonte-Ureña, and Manzano-Agugliaro (2019); Pan et al. (2019); Yuan and Zhang (2020) who revealed that technological innovation contributes to clean energy consumption.

With the rise of energy use, the effect of technological innovation on clean energy consumption will become more significant, and so the advantages of technological innovation will be more and more obvious than export advantages. In addition, energy waste caused by the use of technological innovation will subsequently gradually decrease. It is widely recognized that technological innovation in any country is paramount if clean energy use is to be promoted and implemented because it has less cost and less environmental emission.

Since China is a high-income country and enjoys a high level of technological innovation and encourages innovations and it is involved in international trade. Therefore, it can be easier to improve clean energy use to ensure a more sustainable environment.

Conversely, the coefficient of economic growth is positive and statistically insignificant, this result implies that in the long run, no effect has taken place in clean energy consumption due to changes in economic growth.

Table-4. Long run, short-run and stability analysis for clean energy consumption.

\begin{tabular}{|c|c|c|c|c|}
\hline Variable & Coefficient & Std. error & t-Statistic & Prob. \\
\hline \multicolumn{5}{|l|}{ Panel A. Long-run results } \\
\hline LnEX & $0.1329^{*}$ & 0.0339 & 3.92 & 0.001 \\
\hline LnTI & $0.3335^{*}$ & 0.0255 & 13.08 & 0.000 \\
\hline LnGDPG & 0.08816 & 0.0550 & 1.60 & 0.2010 \\
\hline Constant & $-3.3663 *$ & 0.8215 & -4.10 & 0.000 \\
\hline \multicolumn{5}{|l|}{ Panel B. Short-run results } \\
\hline$\Delta \mathrm{LnTI}$ & $-0.1653^{*} * *$ & 0.0878 & -1.88 & 0.071 \\
\hline $\mathrm{ECM}_{\mathrm{t}-1}$ & $-0.6355^{*}$ & 0.1408 & -4.51 & 0.000 \\
\hline Diagnostic tests & $\chi^{2} / F$-statistics & Prob. & & \\
\hline ARCH LM & 1.298 & 0.2547 & & \\
\hline Breusch-Pagan / Cook-Weisberg & 0.21 & 0.6505 & & \\
\hline White & 25.28 & 0.1908 & & \\
\hline Breusch-Godfrey LM & 0.021 & 0.8841 & & \\
\hline Ramsey RESET & 0.24 & 0.8675 & & \\
\hline CUSUM & Stable & Stable & & \\
\hline Durbin-Watson & & 1.9293 & & \\
\hline
\end{tabular}

Although in short-run exports per capita do not appear any role to clean energy consumption, long-run effects should not be ignored. Currently, the challenges from global climate change are getting more serious, therefore, stimulate exports represents a strategic policy toward the future development of clean energy and environmental situations. Thus, without the consideration of the role of economic growth, an increasing proportion of export per capita and the development of technological innovation can significantly improve China's clean energy consumption which means to reduce emissions.

Panel $\mathrm{B}$ of Table 4 shows the short-run analysis. The value of $\mathrm{ECM}_{\mathrm{t}-1}$ coefficient reflects the speed of adjustment back to the long-run equilibrium after a short-run shock, i.e., how quickly or slowly variables return to the long-run equilibrium from the short-run changes in clean energy consumption. The sign of the $\mathrm{ECM}_{\mathrm{t}-1} \mathrm{estimate}$ is (-0.63.55) negative and statistically significant at the $1 \%$ level, indicating that exists a long-run relationship among the estimated variables. The deviation in clean energy consumption within previous years is corrected by $63.55 \%$ speed towards the equilibrium level of exports per capita, technological innovation and economic growth.

Table 4 shows that in the short-run, a unit increase in technological innovation leads to a decrease in clean energy consumption by $16.53 \%$, but as we mentioned above in the long-run was increased by $33.35 \%$. Therefore, China must continue to speed up the development of energy use and improve the proportion of clean energy consumption depending on technological innovation. 
The technological variable shows the divergent result in the short run, one probable reason for this result is that technology plays an essential role in the China industrialization process and it needs a long term to appear it is effected. Furthermore, in the short-run most industries emit some emissions that coming out from the industries, due to this reason in the short time most industries do not improve the environment in a short time duration respect to technological progress. i.e., when the level of technical progress is below than the threshold in the short run, the increase in energy use will increase some emissions, until the level of technical progress exceeds the turning point in the long run, then it will starts to play a crucial role in increasing clean energy use and reduce the emissions. Thus, when the level of technology innovation achieves a certain critical level, in the long run, it may not lead to decreased clean energy consumption. This evidence is similar to Alam and Murad (2020) who argued that technological reduce clean energy use in the case of France, Iceland, and the United States in the short-term. Furthermore, Gu, Zhao, Yan, Wang, and Li (2019) argue that when energy technological progress develops past in the long run, it could reduce emissions.

The outcome in Table 4 does not appear any role of exports and economic growth on the clean energy margin in the short-run. As evidenced by (zero) optimal lag length for both variables, we described earlier in Table 2. However, the coefficient of exports per capita, in the long run, is positive, and significant at 1 percent level, and consistent with our prior expectation. It also implies that our estimates are not affected by variables-selection bias. This result is in line with Sohag et al. (2015); Alam and Murad (2020) who showed that in the short-run, no effect has taken place in clean energy use due to changes in international trade.

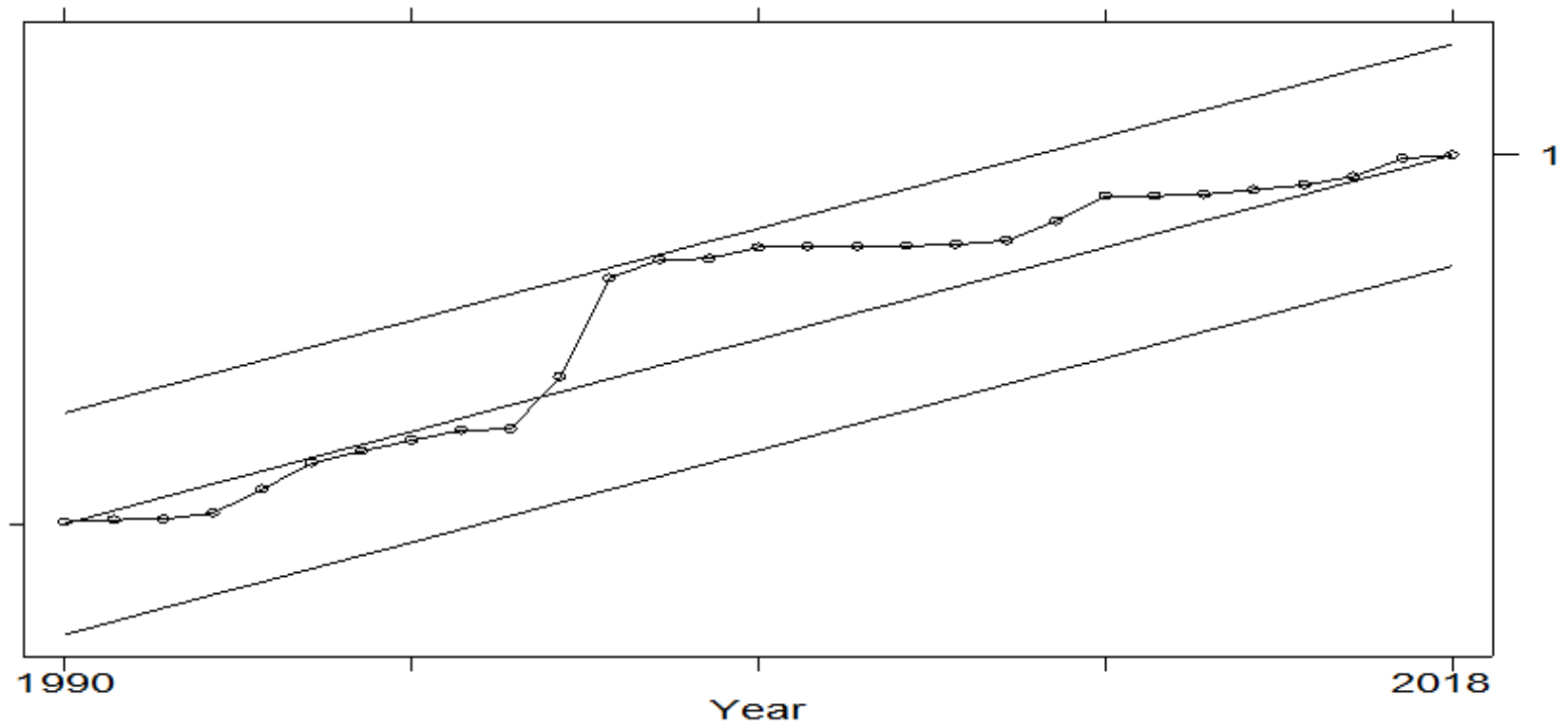

Figure-3. The plot of CUSUM Q. The straight lines indicate significant at 5\%.

The study performs diagnostic tests to check whether the main findings are robust. The results revealed that the model passed all the diagnostic and stability tests. The study materialized, ARCH LM to detect autoregressive conditional heteroscedasticity, Breusch-Pagan/Cook-Weisberg test and white test for heteroskedasticity effects, Breusch Godfrey (B-G) LM test for serial correlation, and the test of Durbin-Watson (D-W) statistics for autocorrelation and Ramsey RESET test for a general specification test and the misspecification. In addition, the study used the tests of CUSUM and CUSUM of Squares to check the stability of the co-integration space in the residuals of the ARDL model, both tests confirmed the model's stability, Figure 3. Shows that the model is stable. 


\subsection{VECM Granger Causality Test}

The existence of co-integration between the variables will confirm to exist at least one causal relationship without to give its direction. Hence, according to the results of Johansen tests for co-integration in Table 3, and following (Engle \& Granger, 1987) for (VECM) model, the results of Granger causality among the series reported in Table 5.

In the short term, the study confirms only one evidence of causality running a unidirectional way from technological innovation to clean energy consumption, suggesting technological innovation can be a crucial role in clean energy. These results support the earlier results in Table 4 which explained that exports and economic growth have no influence effect to clean energy consumption in the short run. Furthermore, in the short-run, our findings detected a neutral effect between the main factor (exports per capita), and clean energy consumption.

Table-5. Results of VECM Granger causality tests.

\begin{tabular}{|c|c|c|c|c|c|}
\hline \multirow{2}{*}{$\begin{array}{l}\text { Dependent } \\
\text { variable }\end{array}$} & \multicolumn{4}{|c|}{ Short-run } & \multirow{2}{*}{$\begin{array}{c}\text { Long-run } \\
\text { ECM }_{t-1}\end{array}$} \\
\hline & $\triangle \mathrm{LnCEC}$ & $\Delta \mathrm{LnEX}$ & $\Delta \operatorname{LnTI}$ & $\triangle \mathrm{LnGDPG}$ & \\
\hline$\triangle \mathrm{LnCEC}$ & $\ldots \ldots$ & $\begin{array}{c}0.019 \\
(0.819) \\
\end{array}$ & $\begin{array}{l}0.231 * * \\
(0.029) \\
\end{array}$ & $\begin{array}{c}0.046 \\
(0.407) \\
\end{array}$ & $\begin{array}{c}-0.6598^{*} \\
(0.000)\end{array}$ \\
\hline$\Delta \mathrm{LnEX}$ & $\begin{array}{c}0.431 \\
(0.318)\end{array}$ & $\ldots \ldots$ & $\begin{array}{c}0.074 \\
(0.768)\end{array}$ & $\begin{array}{c}0.126 \\
(0.349)\end{array}$ & $\begin{array}{c}-1.0340^{* * *} \\
(0.015)\end{array}$ \\
\hline$\Delta \mathrm{LnTI}$ & $\begin{array}{c}0.219 \\
(0.473) \\
\end{array}$ & $\begin{array}{c}0.054 \\
(0.706) \\
\end{array}$ & $\ldots$ & $\begin{array}{c}0.164 \\
(0.084) \\
\end{array}$ & $\begin{array}{c}-1.0504^{*} \\
(0.002)\end{array}$ \\
\hline$\Delta \mathrm{LnGDPG}$ & $\begin{array}{c}0.493 \\
(0.444) \\
\end{array}$ & $\begin{array}{c}0.426 \\
(0.156)\end{array}$ & $\begin{array}{c}0.257 \\
(0.496) \\
\end{array}$ & $\ldots \ldots$ & $\begin{array}{c}-3.8455^{*} \\
(0.000)\end{array}$ \\
\hline
\end{tabular}

In addition, economic growth does not cause clean energy consumption nor does clean energy consumption cause economic growth, which is consistent with the view of Lee. and Chiu (2011) who explained exist the neutrality hypothesis between economic growth and nuclear energy consumption in case of France and the U.S.

Empirical evidence of the long-run causality shows that all the ECTs' coefficients are negative and statistically significant indicating bi-directional causal flows among the variables. These results verify the co-integration test analysis, which was found later.

\section{CONCLUSION AND POLICY IMPLEMENTATION}

The present study is conducted to explore the effect of export volume and main variables on clean energy consumption in China. The results of the bounds test show that in the long-run exports per capita improve clean energy consumption i.e., changes in the volume of export need in China lead to changes in clean energy consumption in longer periods and at increasing rates. The results have several implications; the volume of clean energy consumption increased fivefold in 2018 compared it is the volume in 2000. China has experiences to use more clean energy sources over the years, mainly as China produce and export goods and services. The annual growth rate of China's export in the same period increase by $15.30 \%$ (NBS (National Bureau of Statistics), 2018). Therefore, this study proves that growth in export volume is a catalyst and a major driver of the increase in clean energy consumption in China. Thus, the response of clean energy to exports in the long-run leads to a more optimistic scenario, than what emerges of short-run effects. However, clean energy consumption also calls for important and decisive action as same as to several government priorities to sustainable economic indicators. The results also showed that in long-run technological innovation enhances clean energy use, as the largest emerging economic country, China has effective systems for the development of new technologies, including high energy technologies. Therefore, policymakers can take action to improve energy efficiency through national green technology policies.

The existing study also adapts VECM Granger causality tests. In the short-run, a unidirectional causal exists 
from technological innovation to clean energy consumption. In the long-run a bi-directional causal flow exists between exports and clean energy consumption, indicating that an increase in exports per capita is a core factor driving and improve the energy sector, and the same is true among the variables, validating the feedback hypothesis. As we mentioned earlier, the Chinese government implemented many policies regarding with improvement of energy use, energy intensity, and reduce emissions. Therefore, an increase in clean energy use, which is the main goal of the sustainable economic development of the countries, and it is an alternative energy source that addresses the emission issues without compromising economic growth. Boosts policymakers to increase green energy use by taking some measures of relying more on clean energy from renewable sources and reduce fossil energy consumption, and must take proper initiatives to increase the clean trade, and develop and ease the market accessibility of renewable energy and patent incentive technology, to promote clean energy to ensure sustainable economic development. Our paper is the first step toward clean energy sustainability via international trade that can be considered as empirical analysis in our major.

Funding: This study received no specific financial support.

Competing Interests: The authors declare that they have no competing interests.

Acknowledgement: The authors thank the reviewers for helpful comments and suggestions, and gratefully acknowledge to the editor of this journal

\section{REFERENCES}

Acs, Z. J., Anselin, L., \& Varga, A. (2002). Patents and innovation counts as measures of regional production of new knowledge. Research Policy, 31(7), 1069-1085.Available at: https://doi.org/10.1016/s0048-7333(01)00184-6.

Alam, M. M., \& Murad, M. W. (2020). The impacts of economic growth, trade openness and technological progress on renewable energy use in organization for economic co-operation and development countries. Renewable Energy, 145, 382-390.Available at: https://doi.org/10.1016/j.renene.2019.06.054.

Amri, F. (2017). Intercourse across economic growth, trade and renewable energy consumption in developing and developed countries. Renewable and Sustainable Energy Reviews, 69, 527-534.Available at: https://doi.org/10.1016/j.rser.2016.11.230.

Aznar-Sánchez, J. A., Velasco-Muñoz, J. F., Belmonte-Ureña, L. J., \& Manzano-Agugliaro, F. (2019). Innovation and technology for sustainable mining activity: A worldwide research assessment. Journal of Cleaner Production, 221, 38-54.Available at: https://doi.org/10.1016/j.jclepro.2019.02.243.

Ben Jebli, M., Ben Youssef, S., \& Apergis, N. (2014). The dynamic linkage between CO2 emissions, economic growth, renewable energy consumption, number of tourist arrivals and trade.

Brini, R., Amara, M., \& Jemmali, H. (2017). Renewable energy consumption, International trade, oil price and economic growth inter-linkages: The case of Tunisia. Renewable and Sustainable Energy Reviews, 76, 620-627.Available at: https://doi.org/10.1016/j.rser.2017.03.067.

Brock, W. A., \& Taylor, M. S. (2005). Economic growth and the environment: A review of theory and empirics Handbook of economic growth (Vol. 1, pp. 1749-1821): Elsevier, Canada NBER Working Paper No. 10854.

Chen, Y., Wang, Z., \& Zhong, Z. (2019). CO2 emissions, economic growth, renewable and non-renewable energy production and foreign trade in China. Renewable Energy, 131, 208-216.Available at: https://doi.org/10.1016/j.renene.20 18.07.047.

Chen, J., Cheng, J., \& Dai, S. (2017). Regional eco-innovation in China: An analysis of eco-innovation levels and influencing factors. Journal of Cleaner Production, 153, 1-14.Available at: https://doi.org/10.1016/j.jclepro.2017.03.141.

China Statistics. (2019). China statistical yearbook. Beijing: China Statistics, Press.

Dedeoğlu, D., \& Kaya, H. (2013). Energy use, exports, imports and GDP: New evidence from the OECD countries. Energy Policy, 57, 469-476.Available at: https://doi.org/10.1016/j.enpol.2013.02.016.

Dickey, D. A., \& Fuller, W. A. (1979). Distribution of the estimators for autoregressive time series with a unit root. Journal of the American Statistical Association, 74(366a), 427-431.Available at: https://doi.org/10.2307/2286348. 
Engle, R. F., \& Granger, C. (1987). Co-integration and error correction: representation, estimation, and testing. Econometrica, 55(2), 251-276.Available at: https://doi.org/10.2307/1913236.

GESY. (2019). Global energy statistical yearbook (GESY). Retrieved from: https://www.enerdata.net/publications/worldenergy-statistics-supply-and-demand.html.

Gu, W., Zhao, X., Yan, X., Wang, C., \& Li, Q. (2019). Energy technological progress, energy consumption, and CO2 emissions: Empirical evidence from China. Journal of Cleaner Production, 236, 117666.Available at: https://doi.org/10.1016/j.jclepro.2019.117666.

Haider, S., Adil, M., \& Ganaie, A. (2019). Does industrialisation and urbanisation affect energy consumption: A relative study of India and Iran. Economics Bulletin, 39(1), 176-185.

Johansen, S. (1991). Estimation and hypothesis testing of cointegration vectors in Gaussian vector autoregressive models. Econometrica, 59(6), 1551-1580.Available at: https://doi.org/10.2307/2938278.

Kahrl, F., \& Roland-Holst, D. (2008). Energy and exports in China. China Economic Reviere, 19(4), 649-658.Available at: https://doi.org/10.1016/j.chieco.2008.05.004.

Lean, H. H., \& Smyth, R. (2010). On the dynamics of aggregate output, electricity consumption and exports in Malaysia: evidence from multivariate Granger causality tests. Applied Energy, 87(6), 1963-1971.Available at: https://doi.org/10.1016/j.apenergy.2009.11.017.

Lee, J. W. (2013). The contribution of foreign direct investment to clean energy use, carbon emissions and economic growth. Energy Policy, 55, 483-489.Available at: https://doi.org/10.1016/j.enpol.2012.12.039.

Lee., C.-C., \& Chiu, Y.-B. (2011). Nuclear energy consumption, oil prices, and economic growth: Evidence from highly industrialized countries. Energy Economics, 33(2), 236-248.Available at: https://doi.org/10.1016/j.eneco.2010.07.001.

Lin, B., \& Moubarak, M. (2014). Renewable energy consumption-economic growth nexus for China. Renewable and Sustainable Energy Reviews, 40, 111-117.

Menegaki, A. N. (2011). Growth and renewable energy in Europe: A random effect model with evidence for neutrality hypothesis. Energy Economics, 33(2), 257-263.Available at: https://doi.org/10.1016/j.eneco.2010.10.004.

Narayan, P. K. (2005). The saving and investment nexus for China: Evidence from cointegration tests. Applied Economics, 37(17), 1979-1990.Available at: https://doi.org/10.1080/00036840500278103.

Narayan, P. K., \& Smyth, R. (2009). Multivariate Granger causality between electricity consumption, exports and GDP: Evidence from a panel of Middle Eastern countries. Energy Policy, 37(1), 229-236.Available at: https://doi.org/10.1016/j.enpol.2008.08.020.

Nasreen, S., \& Anwar, S. (2014). Causal relationship between trade openness, economic growth and energy consumption: A panel data analysis of Asian countries. Energy Policy, 69, 82-91.Available at: https://doi.org/10.1016/j.enpol.2014.02.009.

NBS. (2019). National bureau of statistics of China (NBS). Retrieved from: http://www.stats.gov.cn/english/.

NBS (National Bureau of Statistics). (2018). China. Retrieved from: http://www.stats.gov.cn/english/Statisticaldata/AnnualData/.

Ocal, O., \& Aslan, A. (2013). Renewable energy consumption-economic growth nexus in Turkey. Renewable and Sustainable Energy Reviews, 28, 494-499.Available at: https://doi.org/10.1016/j.rser.2013.08.036.

Pan, X., Ai, B., Li, C., Pan, X., \& Yan, Y. (2017). Dynamic relationship among environmental regulation, technological innovation and energy efficiency based on large scale provincial panel data in China. Technological Forecasting and Social Change.Available at: https://doi.org/10.1016/j.techfore.2017.12.012.

Pan, X., Uddin, M. K., Han, C., \& Pan, X. (2019). Dynamics of financial development, trade openness, technological innovation and energy intensity: Evidence from Bangladesh. Energy, 171, 456-464.Available at: https://doi.org/10.1016/j.energy.2018.12.200.

Pesaran, M. H. (1997). The role of economic theory in modelling the long run. The Economic Journal, 107(440), 178-191.Available at: https://doi.org/10.1111/1468-0297.00151. 
Pesaran, M. H., Shin, Y., \& Smith, R. J. (2001). Bounds testing approaches to the analysis of level relationships. Journal of Applied Econometrics, 16(3), 289-326.Available at: https://doi.org/10.1002/jae.616.

Pesaran, M. H., \& Shin, Y. (1998). An autoregressive distributed-lag modelling approach to cointegration analysis. Econometric Society Monographs, 31, 371-413.

Phillips, P. C., \& Hansen, B. E. (1990). Statistical inference in instrumental variables regression with I (1) processes. The Review of Economic Studies, 57(1), 99-125.Available at: https://doi.org/10.2307/2297545.

Phillips, P. C., \& Perron, P. (1988). Testing for a unit root in time series regression. Biometrika, 75(2), 335-346.Available at: https://doi.org/10.1093/biomet/75.2.335.

Rahman, M. M., \& Velayutham, E. (2020). Renewable and non-renewable energy consumption-economic growth nexus: New evidence from South Asia. Renewable Energy, 147, 399-408.Available at: https://doi.org/10.1016/j.renene.2019.09.007.

Sadorsky, P. (2011). Trade and energy consumption in the Middle East. Energy Economics, 33(5), 739-749.Available at: https://doi.org/10.1016/j.eneco.2010.12.012.

Sebri, M., \& Ben-Salha, O. (2014). On the causal dynamics between economic growth, renewable energy consumption, CO2 emissions and trade openness: Fresh evidence from BRICS countries. Renewable and Sustainable Energy Reviews, 39, 1423.Available at: https://doi.org/10.1016/j.rser.2014.07.033.

Shahbaz, M., \& Feridun, M. (2012). Electricity consumption and economic growth empirical evidence from Pakistan. Quality \& Quantity, 46(5), 1583-1599.Available at: https://doi.org/10.1007/s11135-011-9468-3.

Shahbaz, M., Khan, S., \& Tahir, M. I. (2013). The dynamic links between energy consumption, economic growth, financial development and trade in China: Fresh evidence from multivariate framework analysis. Energy Economics, 40, 821.Available at: https://doi.org/10.1016/j.eneco.2013.06.006.

Shahbaz, M., Loganathan, N., Zeshan, M., \& Zaman, K. (2015). Does renewable energy consumption add in economic growth? An application of auto-regressive distributed lag model in Pakistan. Renewable and Sustainable Energy Reviews, 44, 576585.Available at: https://doi.org/10.1016/j.rser.2015.01.017.

Sohag, K., Begum, R. A., Abdullah, S. M. S., \& Jaafar, M. (2015). Dynamics of energy use, technological innovation, economic growth and trade openness in Malaysia. Energy, 90, 1497-1507.Available at: https://doi.org/10.1016/j.energy.2015.06.101.

Tiba, S., \& Frikha, M. (2018). Income, trade openness and energy interactions: Evidence from simultaneous equation modeling. Energy, 147, 799-811.Available at: https://doi.org/10.1016/j.energy.2018.01.013.

Wang, B., \& Wang, Z. (2018). Imported technology and CO2 emission in China: Collecting evidence through bound testing and VECM approach. Renewable and Sustainable Energy Reviews, 82, 4204-4214.Available at: https://doi.org/10.1016/j.rser.2017.11.002.

WEO. (2017). World energy outlook (WEO). Paris: OECD/IEA.

Yuan, J., Xu, Y., Zhang, X., Hu, Z., \& Xu, M. (2014). China's 2020 clean energy target: consistency, pathways and policy implications. Energy Policy, 65, 692-700.Available at: https://doi.org/10.1016/j.enpol.2013.09.061.

Yuan, B., \& Zhang, Y. (2020). Flexible environmental policy, technological innovation and sustainable development of China's industry: The moderating effect of environment regulatory enforcement. Journal of Cleaner Production, 243, 118543.Available at: https://doi.org/10.1016/j.jclepro.2019.118543.

Views and opinions expressed in this article are the views and opinions of the author(s), Asian Development Policy Review shall not be responsible or answerable for any loss, damage or liability etc. caused in relation to/arising out of the use of the content. 